\title{
Predicting response and toxicity to immune checkpoint inhibitors using routinely available blood and clinical markers
}

\author{
Ashley M Hopkins ${ }^{\star 1,2}$, Andrew Rowland ${ }^{1,2}$, Ganessan Kichenadasse ${ }^{1}$, Michael D Wiese ${ }^{3}$, Howard Gurney ${ }^{4}$, \\ Ross A McKinnon ${ }^{1}$, Chris S Karapetis ${ }^{1}$ and Michael J Sorich ${ }^{1,2}$ \\ ${ }^{1}$ Flinders Centre for Innovation in Cancer, College of Medicine and Public Health, Flinders University, Flinders Drive, Bedford Park, \\ Adelaide, South Australia 5042, Australia; ${ }^{2}$ Department of Clinical Pharmacology, College of Medicine and Public Health, Flinders \\ University, Flinders Drive, Bedford Park, Adelaide, South Australia 5042, Australia; ${ }^{3}$ School of Pharmacy and Medical Sciences, \\ University of South Australia, Frome Street, Adelaide, South Australia 5000, Australia and ${ }^{4}$ Department of Medical Oncology, \\ Westmead Hospital, Hawkesbury Road \& Darcy Road, Westmead, Sydney, New South Wales 2145, Australia
}

Immune checkpoint inhibitors $(\mathrm{ICl})$ are an important development in the treatment of advanced cancer. A substantial proportion of patients treated with $\mathrm{ICl}$ do not respond, and additionally patients discontinue treatment due to adverse effects. While many novel biological markers related to the specific mechanisms of $\mathrm{ICl}$ actions have been investigated, there has also been considerable research to identify routinely available blood and clinical markers that may predict response to $\mathrm{ICl}$ therapy. If validated, these markers have the advantage of being easily integrated into clinical use for nominal expense. Several markers have shown promise, including baseline and post-treatment changes in leucocyte counts, lactate dehydrogenase and C-reactive protein. While promising, the results between studies have been inconsistent due to small sample sizes, follow-up time and variability in the assessed markers. To date, research on routinely available blood and clinical markers has focussed primarily on $\mathrm{ICl}$ use in melanoma, the use of ipilimumab and on univariate associations, but preliminary evidence is emerging for other cancer types, other $\mathrm{ICls}$ and for combining markers in multivariable clinical prediction models.

Immune checkpoint inhibitors (ICIs), particularly inhibitors of cytotoxic T-lymphocyte antigen-4 (CTLA-4), programmed death receptor-1 (PD-1) and its associated ligand (PD-L1), represent an important development in the treatment of advanced cancers (Champiat et al, 2016). Unfortunately a substantial proportion of patients treated with ICIs do not respond, while a small proportion of those with survival benefit display a period of apparent treatment failure (pseudoprogression) at the commencement of therapy (Henze et al, 2016). Additionally, ICI use is associated with a spectrum of unique and potentially severe toxicities termed immune-related adverse events (irAEs) (Champiat et al, 2016). Patients may discontinue treatment due to irAEs in a setting, where the necessary duration of treatment is unclear.

Immune checkpoint inhibitors appear capable of producing durable responses compared to existing treatments in a subset of patients with advanced melanoma. Ipilimumab is an anti-CTLA-4 monoclonal antibody (mAb), and, although the proportion of melanoma patients who appear to benefit from treatment remains modest, there is approximately a $10 \%$ increase (doubling) of the survival at 5 years compared to cytotoxic chemotherapy (Garbe et al, 2016; Maio et al, 2015). Additionally, there was a very low mortality rate observed between 3 and 5 years of follow-up (Maio et al, 2015), providing hope that these individuals may continue to respond for many more years. The PD-1 inhibitors, nivolumab and pembrolizumab, are able to achieve a response in a larger proportion of melanoma patients, and although long-term survival data on these therapies are not yet mature, preliminary results are promising (Postow et al, 2015; Ribas et al, 2015; Robert et al, 2015; Robert et al, 2015; Weber et al, 2015; Seetharamu et al, 2016; Topalian et al, 2016). Combination therapy with ipilimumab and a PD-1 inhibitor may further improve response and survival in advanced melanoma, but greater rates of toxicity may occur 
Table 1. Summary of preliminary evidence of routinely available blood and clinical markers predictive of ICl outcomes

\begin{tabular}{|c|c|c|c|c|c|}
\hline Marker & $\mathrm{ICl}$ therapy & Cancer & $N$ & Study results & Reference \\
\hline Lymphocyte count & $\begin{array}{l}\text { Ipilimumab } \\
\text { Ipilimumab } \\
\text { Ipilimumab } \\
\text { Nivolumab }\end{array}$ & $\begin{array}{l}\text { Melanoma } \\
\text { Melanoma } \\
\text { Melanoma } \\
\text { Melanoma }\end{array}$ & $\begin{array}{r}51,73 \\
82,40 \\
95 \\
98\end{array}$ & $\begin{array}{l}\geqslant 1000 \text { per } \mu \mathrm{l} \text { at week } 6 \rightarrow \uparrow \text { OS } \\
\uparrow \text { At } 2-8 \text { weeks vs baseline } \rightarrow \uparrow \\
\text { response } \\
\uparrow \text { At week } 12 \text { vs baseline } \rightarrow \uparrow \text { OS } \\
\geqslant 1000 \text { per } \mu \text { at week } 3-6 \rightarrow \uparrow \text { OS }\end{array}$ & $\begin{array}{l}\text { (Delyon et al, 2013; Ku et al, 2010) } \\
\text { (Bjoern et al, 2016; Martens et al, 2016b) } \\
\text { (Simeone et al, 2014) } \\
\text { (Nakamura et al, 2016) }\end{array}$ \\
\hline Relative lymphocyte count & $\begin{array}{l}\text { Ipilimumab } \\
\text { Pembrolizumab }\end{array}$ & $\begin{array}{l}\text { Melanoma } \\
\text { Melanoma }\end{array}$ & $\begin{array}{l}209 \\
616\end{array}$ & $\begin{array}{l}\uparrow \text { Baseline } \rightarrow \uparrow \text { OS } \\
\uparrow \text { Baseline } \rightarrow \uparrow \text { OS }\end{array}$ & $\begin{array}{l}\text { (Martens et al, 2016a) } \\
\text { (Weide et al, 2016) }\end{array}$ \\
\hline Total leucocyte count & Ipilimumab & Melanoma & 59 & $\downarrow$ Baseline $\rightarrow \uparrow$ response & (Gebhardt et al, 2015) \\
\hline Eosinophil count & $\begin{array}{l}\text { Ipilimumab } \\
\text { Ipilimumab } \\
\text { Ipilimumab }\end{array}$ & $\begin{array}{l}\text { Melanoma } \\
\text { Melanoma } \\
\text { Melanoma }\end{array}$ & $\begin{array}{c}209 \\
59 \\
73\end{array}$ & $\begin{array}{l}\uparrow \text { Baseline } \rightarrow \uparrow \text { OS } \\
\uparrow \text { At week } 3 \text { vs baseline } \rightarrow \uparrow \text { response } \\
\uparrow \text { At week } 6 \text { vs baseline } \rightarrow \uparrow \text { OS }\end{array}$ & $\begin{array}{l}\text { (Martens et al, 2016a) } \\
\text { (Gebhardt et al, 2015) } \\
\text { (Delyon et al, 2013) }\end{array}$ \\
\hline Relative eosinophil count & Pembrolizumab & Melanoma & 616 & $\uparrow$ Baseline $\rightarrow \uparrow$ OS & (Weide et al, 2016) \\
\hline Neutrophil count & $\begin{array}{l}\text { Ipilimumab } \\
\text { Ipilimumab } \\
\text { Nivolumab }\end{array}$ & $\begin{array}{l}\text { Melanoma } \\
\text { Melanoma } \\
\text { Melanoma }\end{array}$ & $\begin{array}{c}59 \\
720 \\
98\end{array}$ & $\begin{array}{l}\downarrow \text { Baseline } \rightarrow \uparrow \text { response } \\
\downarrow \text { Baseline } \rightarrow \uparrow \text { PFS and OS } \\
<4000 \text { per } \mu \text { l at week } 3-6 \rightarrow \uparrow \text { OS }\end{array}$ & $\begin{array}{l}\text { (Gebhardt et al, 2015) } \\
\text { (Ferrucci et al, 2016) } \\
\text { (Nakamura et al, 2016) }\end{array}$ \\
\hline Neutrophil/lymphocyte ratio & $\begin{array}{l}\text { Ipilimumab } \\
\text { Ipilimumab } \\
\text { Nivolumab }\end{array}$ & $\begin{array}{l}\text { Melanoma } \\
\text { Melanoma } \\
\text { NSCLC }\end{array}$ & $\begin{array}{c}58,185 \\
187 \\
175\end{array}$ & $\begin{array}{l}\downarrow \text { Baseline } \rightarrow \uparrow \text { OS } \\
\downarrow \text { Baseline } \rightarrow \uparrow \text { PFS and OS } \\
\downarrow \text { Baseline } \rightarrow \uparrow \text { OS }\end{array}$ & $\begin{array}{l}\text { (Khoja et al, 2016; Zaragoza et al, 2016) } \\
\text { (Ferrucci et al, 2015) } \\
\text { (Bagley et al, 2017) }\end{array}$ \\
\hline $\begin{array}{l}\text { Derived neutrophil/ } \\
\text { lymphocyte ratio }\end{array}$ & Ipilimumab & Melanoma & 720 & $\downarrow$ Baseline $\rightarrow \uparrow$ PFS and OS & (Ferrucci et al, 2016) \\
\hline Monocyte count & Ipilimumab & Melanoma & 209 & $\downarrow$ Baseline $\rightarrow \uparrow$ OS & (Martens et al, 2016a) \\
\hline Lactate dehydrogenase & $\begin{array}{l}\text { Ipilimumab } \\
\text { Nivolumab } \\
\text { Pembrolizumab } \\
\text { Pembrolizumab, } \\
\text { nivolumab } \\
\text { Ipilimumab }\end{array}$ & $\begin{array}{l}\text { Melanoma } \\
\text { Melanoma } \\
\text { Melanoma } \\
\text { Melanoma }\end{array}$ & $\begin{array}{c}209,73 \\
166,58 \\
113,183 \\
\\
98 \\
616 \\
66 \\
95\end{array}$ & $\begin{array}{l}\downarrow \text { Baseline } \rightarrow \uparrow \text { OS } \\
\\
\uparrow \text { Baseline } \rightarrow \downarrow \text { OS } \\
\downarrow \text { Baseline } \rightarrow \uparrow \text { OS } \\
\downarrow \text { Baseline } \rightarrow \uparrow \text { OS } \\
\uparrow \text { At week } 12 \text { vs baseline } \rightarrow \\
\downarrow \text { Response, OS } \\
\downarrow \text { At week } 12 \rightarrow \uparrow \text { response and OS }\end{array}$ & $\begin{array}{l}\text { (Delyon et al, 2013; Kelderman et al, } \\
\text { 2014; Valpione et al, 2015; Collins and Le } \\
\text { Manach, 2016; Dick et al, 2016; Khoja } \\
\text { et al, 2016; Zaragoza et al, 2016; Martens } \\
\text { et al, 2016a) } \\
\text { (Nakamura et al, 2016) } \\
\text { (Weide et al, 2016) } \\
\text { (Diem et al, 2016) } \\
\text { (Simeone et al, 2014) }\end{array}$ \\
\hline C-reactive protein & Ipilimumab & Melanoma & 95 & $\downarrow$ At week $12 \rightarrow \uparrow$ response and OS & (Simeone et al, 2014) \\
\hline Smoking status & Nivolumab & & 88 & Current/former smokers $\rightarrow \uparrow$ response & (Hellmann et al, 2014) \\
\hline ECOG PS & $\begin{array}{l}\text { Nivolumab } \\
\text { Nivolumab }\end{array}$ & $\begin{array}{l}\text { Melanoma } \\
\text { NSCLC }\end{array}$ & $\begin{array}{c}98 \\
175\end{array}$ & $\begin{array}{l}<1 \text { at baseline } \rightarrow \uparrow \text { OS } \\
<2 \text { at baseline } \rightarrow \uparrow \text { OS }\end{array}$ & $\begin{array}{l}\text { (Nakamura et al, 2016) } \\
\text { (Bagley et al, 2017) }\end{array}$ \\
\hline Liver metastases & Nivolumab & NSCLC & 175 & Presence at baseline $\rightarrow \downarrow$ OS & (Bagley et al, 2017) \\
\hline irAE & $\begin{array}{l}\text { Ipilimumab } \\
\text { Ipilimumab } \\
\text { Nivolumab } \\
\text { Nivolumab } \\
\text { Pembrolizumab } \\
\text { Immunotherapy }\end{array}$ & $\begin{array}{l}\text { Melanoma } \\
\text { Melanoma } \\
\text { Melanoma } \\
\text { Melanoma } \\
\text { Melanoma } \\
\text { Melanoma }\end{array}$ & $\begin{array}{c}139 \\
298 \\
576 \\
148 \\
67 \\
622\end{array}$ & $\begin{array}{l}\text { Early irAE } \rightarrow \uparrow \text { response } \\
\text { No association with OS } \\
\text { Any-grade } A E \rightarrow \uparrow \text { response } \\
\text { Rash, vitiligo and any grade } A E \rightarrow \uparrow \\
\text { OS } \\
\text { Vitiligo } \rightarrow \uparrow \text { objective response } \\
\text { vitiligo-like depigmentation } \rightarrow \uparrow \text { OS }\end{array}$ & $\begin{array}{l}\text { (Downey et al, 2007) } \\
\text { (Horvat et al, 2015) } \\
\text { (Weber et al, 2017) } \\
\text { (Freeman-Keller et al, 2016) } \\
\text { (Hua et al, 2016) } \\
\text { (Teulings et al, 2015) }\end{array}$ \\
\hline Body composition & Ipilimumab & Melanoma & 84 & $\begin{array}{l}\text { Baseline sarcopenia or low muscle } \\
\text { attenuation } \rightarrow \text { severe treatment- } \\
\text { related toxicity }\end{array}$ & (Daly et al, 2017) \\
\hline
\end{tabular}

compared to PD-1 therapy alone (Postow et al, 2015; Topalian et al, 2016).

Substantial survival benefits with nivolumab and pembrolizumab have also been demonstrated for other cancers, including non-small-cell lung cancer (NSCLC), urothelial cancer, metastatic renal cell carcinoma (mRCC) (Borghaei et al, 2015; Brahmer et al, 2015; Garon et al, 2015; Motzer et al, 2015; Champiat et al, 2016; Bellmunt et al, 2017; Sharma et al, 2017). Preliminary outcomes from trials evaluating other non-approved anti-PD-1 (pidilizumab) and anti-PD-L1 (atezolizumab, durvalumab, avelumab and BMS936559) $\mathrm{mAbs}$ are also displaying promising response rates for a range of cancers (Barbee et al, 2015; Rittmeyer et al, 2016; Rosenberg et al, 2016; Seetharamu et al, 2016). If these ongoing trials confirm the expected effects on survival, there will be significant growth in the patient populations using ICIs, and thus optimising outcomes becomes increasingly important.

There has been extensive research of novel biological markers that are specific to the mechanism of actions of ICI that may predict response to therapy and these markers have been recently and extensively reviewed (Meng et al, 2015; Topalian et al, 2016; Gnjatic et al, 2017). In parallel, there has also been considerable research conducted to identify if any routinely available blood and clinical markers are predictive of response and toxicity to ICIs. If validated to be predictive, routinely available blood and clinical markers have the advantage of being readily available in the clinic, and hence easily and quickly integrated in clinical decisionmaking. It is biologically plausible that some routinely available markers, such as peripheral blood lymphocyte count, may provide 
insight into the activity of the immune system and hence provide the capacity for the immune system to mediate a strong antitumour effect in the presence of ICI therapy (Pardoll, 2012). The association between routinely available blood and clinical markers and ICI response/toxicity is, therefore, the focus of this review.

\section{SEARCH PROCESS}

Studies investigating the association between routinely available blood and clinical markers and ICI response/toxicity were identified through a structured search of Scopus and then Google Scholar in July 2017. The search terms included the name of FDA approved ICI's (atezolizumab, avelumab, durvalumab, ipilimumab, nivolumab and pembrolizumab), 'biomarker' OR 'marker' OR 'predictor', plus 'response' OR 'survival' OR 'toxicity'. Studies were included if they reported investigation of the association between routinely available blood and clinical markers and ICI response or toxicity. References and citations of selected studies were handsearched for reference to any additional relevant studies.

\section{POTENTIAL PREDICTORS OF ICI EFFICACY}

The relatively modest response rate with ICI therapy, coupled with the potential to achieve long-term response in those who do respond, suggests that the discovery of markers that predict ICI efficacy would be useful. Many biomarkers are being explored for ICI therapy and these are reviewed in depth elsewhere (Meng et al, 2015; Topalian et al, 2016; Gnjatic et al, 2017). In brief, predictive biomarkers proposed for ipilimumab response include baseline expression of CD ${ }^{+} \mathrm{ICOS}^{\text {high }}$ and $\mathrm{Ki} 67^{+} \mathrm{EOMES}^{+} \mathrm{CD} 8^{+}$T-cells, increased FOXP3 and indoleamine 2,3-dioxygenase expression, and reduced expression of regulatory T cells (Ascierto et al, 2013). Circulating baseline levels of TGF- $\beta 1$ and IL-10 are also proposed prognostic markers for relapse following ipilimumab therapy. Expression of PD-L1, particularly on infiltrating myeloid and T cells, but not tumour cells, is currently a promising predictive biomarker of response for anti-PD-1/PD-L1 mAbs, and positive expression of PD-L1 is associated with improved response rate, progression-free survival and overall response in a number of studies (Meng et al, 2015; Topalian et al, 2016). However, PD-L1negative tumours may still respond to treatment. While mechanistically plausible, there is currently limited evidence for genetic and epigenetic markers such as miR34 expression (Remon et al, 2016). Exploratory analyses have shown The Cancer Genome Atlas (TCGA) subtypes and mutation load to be predictive of response to atezolizumab used in the treatment of metastatic urothelial carcinoma (Rosenberg et al, 2016). Programmed death receptor ligand-2, interferon gamma, EGFR mutations and anaplastic lymphoma kinase (ALK) rearrangements may represent novel biomarkers that could be explored further in the future (Gainor et al, 2016; Remon et al, 2016).

While the above-mentioned biomarkers may predict efficacy and improved response rates to ICIs, there would be a cost to integrating their measurement into clinical care. In contrast, several small retrospective investigations have evaluated routinely available blood and clinical markers that may predict therapeutic benefit from ICIs (Table 1). To date, the majority of investigations have focussed on ipiliumumab, nivolumab or pembrolizumab in the treatment of melanoma. Baseline and post-treatment changes in leucocyte counts, lactate dehydrogenase $(\mathrm{LDH})$ and C-reactive protein all show promise as predictive biomarkers for response (Table 1). A recent report highlights that smoking status may also be relevant (Hellmann et al, 2014), while the pattern of visceral metastasis has also been associated with changes to survival outcomes (Weide et al, 2016). Adverse events may also be a possible determinate of response to ICI therapy, albeit reports are inconsistent at this stage (Table 1).

Leucocyte count. Baseline and post-treatment changes in leucocytes including lymphocytes, eosinophils, neutrophils, neutrophil to lymphocyte ratio and monocytes counts are promising routinely available blood markers that have shown associations with response to ICI therapy (Table 1). Baseline changes in myeloidderived suppressor cells (MDSCs) (Martens et al, 2016a) and regulatory $\mathrm{T}$ cells (Martens et al, 2016a, b) have also been associated with response to ICI therapy but are not currently routinely available leucocyte markers. Several of these leucocyte markers have shown associations across multiple studies with the direction of response generally aligning. However, differences between study designs, methodology, marker measurement and marker use have limited the ability to identify the effect size. In particular, there are significant inconsistencies between the leucocytes measured, the use of absolute or relative counts, the use of a baseline or a landmark analysis approach and the marker cut-point that most clearly distinguishes individuals likely and unlikely to respond to therapy.

As ipilimumab blocks CTLA-4 expressed on various lymphocyte populations, a high peripheral blood lymphocyte count may reflect a greater capacity of the immune system to mediate a strong antitumour effects in the presence of ipilimumab (Ku et al, 2010). Accordingly, the potential association between lymphocyte counts and ipilimumab response has been investigated in several studies. In melanoma patients treated with ipilimumab, high and increased absolute lymphocyte counts (ALC) at 2-12 weeks after treatment initiation have been associated with improved response and overall survival (OS) (Delyon et al, 2013; Ku et al, 2010; Martens et al, 2016b; Simeone et al, 2014). These results have been demonstrated in small cohorts ranging from 51 to 95 melanoma patients treated with ipilumumab at 3 and $10 \mathrm{mg} \mathrm{kg}^{-1}$ every 3 weeks at European and American sites (Delyon et al, 2013; Ku et al, 2010; Martens et al, 2016b; Simeone et al, 2014). Martens et al (2016a) did not confirm these results, but did find that an increased relative lymphocyte count (RLC; percent of leucocytes that are lymphocytes) at baseline was associated with improved OS $(n=204)$. In one of the largest studies to investigate an association between lymphocytes and response to ICI to date $(n=616$, European and American melanoma patients), no association was found with ALC, but increased RLC at baseline was associated with improved OS (Weide et al, 2016). Similarly, Wolchok et al (2013) found no association between increased ALC and response in melanoma patients treated with nivolumab and ipilimumab, although the study population was small $(n=53)$ and did not assess RLC. Similar inconsistencies in results have been demonstrated for eosinophil and neutrophil counts, and for neutrophil to lymphocyte ratios (Delyon et al, 2013; Wolchok et al, 2013; Ferrucci et al, 2015; Gebhardt et al, 2015; Ferrucci et al, 2016; Martens et al, 2016a; Weide et al, 2016; Zaragoza et al, 2016).

Despite these inconsistencies, leucocytes counts are among the most promising routinely available blood markers that may be able to predict response to ICI therapy. For example, Ku et al (2010) indicated that an ALC $>1000$ cells per $\mu \mathrm{l}$ at week 7 correlated with a significantly improved clinical benefit rate (17 of 33 patients (51\%) vs 0 of $8 ; P<0.01)$ and median OS (11.9 vs 1.4 months; $P<0.001)$ compared with those with an ALC $<1000$ cells per $\mu$ l. While Ferrucci et al (2016) indicated that patients with an absolute neutrophil count (ANC) $>7500$ cells per $\mu$ l and a derived neutrophil/lymphocyte ratio $(\mathrm{dNLR})>3$ had a significantly increased risk of death (hazard ratio $(\mathrm{HR})=5.76$; $95 \%$ confidence interval (CI) 4.29-7.75) and disease progression ( $\mathrm{HR}=4.10 ; 95 \%$ CI 3.08-5.46) compared to patients with a lower ANC and dNLR. 
Such results indicate that leucocyte and leucocyte sub-type counts may be able to be used in the clinic to spare patients potentially ineffective or toxic treatments, and thus allow the commencement of alternate treatments.

Variability in study design makes it difficult to compare results across studies. For example, Ferrucci et al (2016) conducted the largest study to date to assess leucocytes associations with response to ipilimumab treatment in melanoma patients $(n=720$, Italian melanoma patients treated with $3 \mathrm{mg} \mathrm{kg}^{-1}$ of ipilimumab every 3 weeks). However only absolute neutrophil and total leucocyte counts were available to researchers, but not lymphocyte, monocyte, eosinophil and basophil counts. Thus, it would be desirable to conduct a large study assessing all the routinely collected leucocyte counts to determine the most suitable marker of response/toxicity.

Lactate dehydrogenase. Elevated $\mathrm{LDH}$ levels are a prognostic factor for poor survival outcomes in patients with metastatic melanoma, mRCC and many other tumour types. This is recognised by the American Joint Committee on Cancer (AJCC), which includes LDH levels as part of their melanoma staging and classification system (Balch et al, 2009). Normal baseline LDH is associated with improved response and OS in melanoma patients treated with ipilimumab, pembrolizumab and nivolumab (Delyon et al, 2013; Simeone et al, 2014; Valpione et al, 2015; Collins and Le Manach, 2016; Diem et al, 2016; Khoja et al, 2016; Weide et al, 2016; Zaragoza et al, 2016; Martens et al, 2016a). The potential clinical importance of this finding is reflected in a real-world cohort of melanoma patients treated with nivolumab or pembrolizumab, in which half had elevated LDH levels at baseline (Diem et al, 2016). Post treatment increases in LDH levels were also associated with poorer response and survival in this cohort (Diem et al, 2016). Further demonstrating the potential clinical importance of LDH levels is the multivariable analysis conducted by Martens et al (2016a), which identified that normal baseline $\mathrm{LDH}$, absolute monocyte counts, MDSCs frequencies, absolute eosinophil count, RLC and regulatory T cells (Treg) frequencies were associated with improved survival in ipilimumab-treated melanoma patients. In this analysis, $\mathrm{LDH}$ was a strong predictor of improved outcomes, with a median OS of 10 months for patients with baseline LDH up to 1.2-fold higher than the upper limit of normal, while for those $>1.2$ - and $>2.3$-fold, it was only 5 and 2 months, respectively $(P<0.0001)$ (Martens et al, 2016a).

\footnotetext{
Adverse events. Adverse events have been associated with response to a number of cancer medicines, in particular the targeted medications. For example, proteinuria was recently identified as being associated with improved survival in mRCC patients treated with vascular endothelial growth factor targeted agents (Sorich et al, 2016). In a meta-analysis of 137 studies evaluating cancer immunotherapies (including 11 general immune stimulation, 84 vaccine, 28 antibody-based and 16 adoptive transfer treatment arms), a strong association between vitiligo-like depigmentation and survival was also identified $(P<0.024)$, but the association for ICI therapies specifically is unknown (Teulings et al, 2015). Since that time the irAE vitiligo has also been associated with improved objective response in a melanoma cohort treated with pembrolizumab (Hua et al, 2016), and survival in a melanoma cohort treated with nivolumab (Freeman-Keller et al, 2016). However both studies were relatively small and evidence on whether irAE are predictive of ICI response/survival, including but not limited to vitiligo, requires clarification in larger studies (Weber et al, 2017). Greater exposure to ipilimumab (i.e., higher plasma drug concentrations) is associated with increased response/ survival and higher rates of irAEs (Feng et al, 2013), which is suggestive that irAE may predict response and survival.
}

\section{POTENTIAL PREDICTORS OF ICI TOXICITY}

Immune checkpoint inhibitors have been associated with severe irAEs such as rash, diarrhoea, colitis, hypophysitis, hepatotoxicity and hypothyroidism (Champiat et al, 2016). Severe irAEs are more common with ipilimumab (15-43\% of patients) than nivolumab or pembrolizumab. However, $\sim 10-20 \%$ of patients treated with antiPD-1 mAbs still develop severe, potentially life-threatening toxicities, and this increases further when combining with antiCTLA-4 and anti-PD-1 mAbs (Postow et al, 2015; Champiat et al, 2016; Topalian et al, 2016). Potential predictors of ICI toxicity and irAEs have been less thoroughly investigated than predictors for response. Although, the presence of baseline sarcopenia and low muscle attenuation were recently associated with the occurrence of severe treatment-related toxicity (Daly et al, 2017). Several other potential baseline risk factors for severe irAEs have also been proposed, including family history of autoimmune diseases, tumour infiltration and location, previous viral infections such as HIV or hepatitis and the concomitant use of medicines with known autoimmune toxicities such as antiarrhythmics, antibiotics, anticonvulsants or antipsychotics (Champiat et al, 2016; Manson et al, 2016). A small study recently indicated that ipilimumabtreated patients experiencing irAEs appear to present with a diversification of the T-cell repertoire (Fong et al, 2016; Oh et al, 2017), while increased eosinophil count has also been linked to irAEs (Schindler et al, 2014). Another small study found that increased circulating IL-17 levels might be associated with gastrointestinal toxicity (Tarhini et al, 2015); however in general the investigation of predictors of ICI toxicity requires increased research.

\section{FUTURE PERSPECTIVE}

Following ICI therapy initiation, some patients have an influx of effector cells to the tumour masses and an apparent increase in tumour size (pseudoprogression) (Henze et al, 2016). To improve the assessment of the effect of immunotherapeutic agents, the immune-related Response Evaluation Criteria in Solid Tumors (irRECIST) was developed (Henze et al, 2016), while research continues to explore novel methods to detect early response to ICI. These factors exemplify the importance of identifying predictive markers of response that may justify continued therapy in lieu of a traditional response profile. To facilitate the translation of identified predictors into clinical strategies, prospective investigations comparing standard practices against modified strategies will be required. In this manuscript, we have focussed on compiling the studies that have identified routinely available blood and clinical markers associated with response and toxicity to ICIs. The benefits of such markers are that once validated they will generally be easily available and not require additional costs or setup to integrate into clinical care. Future research will also continue to explore other biomarkers routinely collected in the clinic that may predict response to ICI therapy. Biological plausibility and pilot investigations indicate that performance status, age, concomitant therapy (particularly high-dose corticosteroids), diversity of gut microbiome, prolactin, autoimmune diseases status, human leucocyte antigen class, DNA mismatch repair complex (MMR complex), tumour characteristics (size, location of metastases) and the level of tumour infiltrating lymphocytes are potential markers that should be more thoroughly investigated in the future (Friedman and Postow, 2016; Nishijima et al, 2016; Seliger, 2016; Topalian et al, 2016; Caponnetto et al, 2017; Wargo et al, 2017; Johnson et al, 2017).

To date, most of the research investigating routinely available blood and clinical markers as predictors of ICI response and 
toxicity has focused on ipilimumab and ICIs used in the treatment of melanoma. Recent preliminary evidence is now emerging that survival of NSCLC and urothelial cancer patients treated with ICI therapy is associated with markers such as low baseline NLR, low baseline performance status, the presence of liver metastases, increasing albumin, decreasing NLR and decreasing clearance (Bagley et al, 2017; Powles et al, 2017). Despite this there is notably less research evaluating routinely available blood and clinical markers as predictors of outcomes for the newer anti-PD-1/PD-L1 drugs and other cancer types. Given the promising evidence emerging for ICIs and their growing use, this represents an important unmet area of research and care must currently be taken in generalising the predominantly melanoma studies to other cancer types. Weide et al (2016) did assess melanoma patients treated with pembrolizumab, and reported a combination model (based on relative eosinophil count, RLC, LDH and the absence of metastasis other than soft-tissue/lung) that could be assessed in a randomised controlled trial to determine the predictive benefit of the model on treatment decisions. Emerging evidence also indicates that combination therapy with anti-PD-1 and antiCTLA-4 mAbs increases response rate, albeit at the expense of increased toxicity. Thus, trials examining combination therapies will likely continue into the future. This manuscript highlights the importance of trials collecting potential biomarker data that may facilitate improved responses and toxicity avoidance in those receiving combination therapies in the future.

Of the studies presented, there is considerable variability in the collected and assessed routinely available blood and clinical markers. Given the array of potential pathways and biomarkers that have been implicated in ICI efficacy and the complexity of the tumour environment and immune function, it is likely that a combination of multiple predictors will be required to effectively predict response and toxicity of ICI therapy (Martens et al, 2016a). Despite this, many of the studies presented herein lacked access to all the potential biomarkers. For example Ku et al (2010) assessed the association of ALC with OS following ipilimumab treatment using a landmark approach adjusted for baseline LDH levels $(n=53)$, while Ferrucci et al (2016) had the largest study population to date $(n=720)$, but only had access to neutrophil and total leucocyte counts. Opposing this, Martens et al (2016a) assessed MDSCs and Treg frequencies, LDH, monocytes, eosinophils, lymphocytes and several other clinical characteristics for associations with OS in ipilimumab treatment melanoma patients. Such a screening processes enabled the development of a multivariable model, which may improve clinical decisions over the use of a single biomarker alone. In addition to the importance of the continued investigation of potential biomarkers in multivariable analyses, dose modification strategies and therapeutic drug monitoring techniques should also be considered as mechanisms to improve response and toxicity to ICI, but have not been extensively explored.

\section{CONCLUSION}

Immune checkpoint inhibitors are an emerging option in the treatment of melanoma and other advanced cancers. However, a substantial proportion of patients do not respond to ICIs, while they can be associated with a range of potentially life-threatening irAEs. Several potential predictors of ICI response and toxicity have been proposed, including routinely available blood and clinical markers. However to date these have not been extensively explored, particularly for the newer nivolumab or pembrolizumab. Several small retrospective investigations have identified association between pre- and post-treatment blood and clinical markers, and response to ipilimumab. While promising and easy to use in the clinic, these predictive markers require validation in adequately powered and well-designed multivariable analyses.

\section{ACKNOWLEDGEMENTS}

Ashley Hopkins is a researcher funded by a Postdoctoral Fellowship from the National Breast Cancer Foundation, Australia. This manuscript was produced with the financial and other support of Cancer Council SA's Beat Cancer Project on behalf of its donors and the State Government of South Australia through the Department of Health.

\section{CONFLICT OF INTEREST}

The authors declare no conflict of interest.

\section{AUTHOR CONTRIBUTIONS}

All authors were involved in the conception, design, acquisition of information and drafting of this review article. All authors have approved the final article.

\section{REFERENCES}

Ascierto PA, Kalos M, Schaer DA, Callahan MK, Wolchok JD (2013) Biomarkers for immunostimulatory monoclonal antibodies in combination strategies for melanoma and other tumor types. Clin Cancer Res 19(5): 1009-1020.

Bagley SJ, Kothari S, Aggarwal C, Bauml JM, Alley EW, Evans TL, Kosteva JA, Ciunci CA, Gabriel PE, Thompson JC, Stonehouse-Lee S, Sherry VE, Gilbert E, Eaby-Sandy B, Mutale F, DiLullo G, Cohen RB, Vachani A, Langer CJ (2017) Pretreatment neutrophil-to-lymphocyte ratio as a marker of outcomes in nivolumab-treated patients with advanced nonsmall-cell lung cancer. Lung Cancer 106: 1-7.

Balch CM, Gershenwald JE, Soong S-J, Thompson JF, Atkins MB, Byrd DR, Buzaid AC, Cochran AJ, Coit DG, Ding S, Eggermont AM, Flaherty KT, Gimotty PA, Kirkwood JM, McMasters KM, Mihm MC, Morton DL, Ross MI, Sober AJ, Sondak VK (2009) Final version of 2009 AJCC Melanoma Staging and Classification. J Clin Oncol 27(36): 6199-6206.

Barbee MS, Ogunniyi A, Horvat TZ, Dang T-O (2015) Current status and future directions of the immune checkpoint inhibitors ipilimumab, pembrolizumab, and nivolumab in oncology. Ann Pharmacother 49(8): 907-937.

Bellmunt J, de Wit R, Vaughn DJ, Fradet Y, Lee J-L, Fong L, Vogelzang NJ, Climent MA, Petrylak DP, Choueiri TK, Necchi A, Gerritsen W, Gurney H, Quinn DI, Culine S, Sternberg CN, Mai Y, Poehlein CH, Perini RF, Bajorin DF (2017) Pembrolizumab as second-line therapy for advanced urothelial carcinoma. N Engl J Med 376(11): 1015-1026.

Bjoern J, Juul Nitschke N, Zeeberg Iversen T, Schmidt H, Fode K, Svane IM (2016) Immunological correlates of treatment and response in stage IV malignant melanoma patients treated with Ipilimumab. Oncoimmunology 5(4): e1100788.

Borghaei H, Paz-Ares L, Horn L, Spigel DR, Steins M, Ready NE, Chow LQ, Vokes EE, Felip E, Holgado E, Barlesi F, Kohlhäufl M, Arrieta O, Burgio MA, Fayette J, Lena H, Poddubskaya E, Gerber DE, Gettinger SN, Rudin CM, Rizvi N, Crinò L, Blumenschein GRJ, Antonia SJ, Dorange C, Harbison CT, Graf Finckenstein F, Brahmer JR (2015) Nivolumab versus Docetaxel in advanced nonsquamous non-small-cell lung cancer. $N$ Engl J Med 373(17): 1627-1639.

Brahmer J, Reckamp KL, Baas P, Crinò L, Eberhardt WEE, Poddubskaya E, Antonia S, Pluzanski A, Vokes EE, Holgado E, Waterhouse D, Ready N, Gainor J, Arén Frontera O, Havel L, Steins M, Garassino MC, Aerts JG, Domine M, Paz-Ares L, Reck M, Baudelet C, Harbison CT, Lestini B, Spigel DR (2015) Nivolumab versus Docetaxel in advanced squamous-cell non-small-cell lung cancer. N Engl J Med 373(2): 123-135. 
Caponnetto S, Iannantuono GM, Barchiesi G, Magri V, Gelibter A, Cortesi E (2017) Prolactin as a potential early predictive factor in metastatic nonsmall cell lung cancer patients treated with Nivolumab. Oncology 93(1): $62-66$.

Champiat S, Lambotte O, Barreau E, Belkhir R, Berdelou A, Carbonnel F, Cauquil C, Chanson P, Collins M, Durrbach A, Ederhy S, Feuillet S, François H, Lazarovici J, Le Pavec J, De Martin E, Mateus C, Michot JM, Samuel D, Soria JC, Robert C, Eggermont A, Marabelle A (2016) Management of immune checkpoint blockade dysimmune toxicities: a collaborative position paper. Ann Oncol 27(4): 559-574.

Collins GS, Le Manach Y (2016) Small data sets to develop and validate prognostic models are problematic. Eur J Cancer 54: 167-168.

Daly LE, Power DG, O’Reilly A, Donnellan P, Cushen SJ, O'Sullivan K, Twomey M, Woodlock DP, Redmond HP, Ryan AM (2017) The impact of body composition parameters on ipilimumab toxicity and survival in patients with metastatic melanoma. Br J Cancer 116(3): 310-317.

Delyon J, Mateus C, Lefeuvre D, Lanoy E, Zitvogel L, Chaput N, Roy S, Eggermont AMM, Routier E, Robert C (2013) Experience in daily practice with ipilimumab for the treatment of patients with metastatic melanoma: an early increase in lymphocyte and eosinophil counts is associated with improved survival. Ann Oncol 24(6): 1697-1703.

Dick J, Lang N, Slynko A, Kopp-Schneider A, Schulz C, DimitrakopoulouStrauss A, Enk AH, Hassel JC (2016) Use of LDH and autoimmune side effects to predict response to ipilimumab treatment. Immunotherapy 8(9): 1033-1044.

Diem S, Kasenda B, Spain L, Martin-Liberal J, Marconcini R, Gore M, Larkin J (2016) Serum lactate dehydrogenase as an early marker for outcome in patients treated with anti-PD-1 therapy in metastatic melanoma. $\mathrm{Br} J$ Cancer 114(3): 256-261.

Downey SG, Klapper JA, Smith FO, Yang JC, Sherry RM, Royal RE, Kammula US, Hughes MS, Allen TE, Levy CL, Yellin M, Nichol G, White DE, Steinberg SM, Rosenberg SA (2007) Prognostic factors related to clinical response in patients with metastatic melanoma treated by CTL-associated antigen-4 blockade. Clin Cancer Res 13(22): 6681-6688.

Feng Y, Roy A, Masson E, Chen TT, Humphrey R, Weber JS (2013) Exposureresponse relationships of the efficacy and safety of ipilimumab in patients with advanced melanoma. Clin Cancer Res 19(14): 3977-3986.

Ferrucci PF, Ascierto PA, Pigozzo J, Del Vecchio M, Maio M, Antonini Cappellini GC, Guidoboni M, Queirolo P, Savoia P, Mandala M, Simeone E, Valpione S, Altomonte M, Spagnolo F, Cocorocchio E, Gandini S, Giannarelli D, Martinoli C (2016) Baseline neutrophils and derived neutrophil-to-lymphocyte ratio: prognostic relevance in metastatic melanoma patients receiving ipilimumab. Ann Oncol 27(4): 732-738.

Ferrucci PF, Gandini S, Battaglia A, Alfieri S, Di Giacomo AM, Giannarelli D, Cappellini GCA, De Galitiis F, Marchetti P, Amato G, Lazzeri A, Pala L, Cocorocchio E, Martinoli C (2015) Baseline neutrophil-to-lymphocyte ratio is associated with outcome of ipilimumab-treated metastatic melanoma patients. Br J Cancer 112(12): 1904-1910.

Fong L, Oh DY, Cham J, Zhang L, Fong G, Kwek SS, Klinger M, Faham M (2016) T cell repertoire diversification is associated with immune related toxicities following CTLA-4 blockade in cancer patients. Cancer Res; epub a head of print 28 December 2016; doi:10.1158/0008-5472.CAN-16-2324.

Freeman-Keller M, Kim Y, Cronin H, Richards A, Gibney G, Weber JS (2016) Nivolumab in resected and unresectable metastatic melanoma: characteristics of immune-related adverse events and association with outcomes. Clin Cancer Res 22(4): 886-894.

Friedman CF, Postow MA (2016) Emerging tissue and blood-based biomarkers that may predict response to immune checkpoint inhibition. Curr Oncol Rep 18(4): 21.

Gainor JF, Shaw AT, Sequist LV, Fu X, Azzoli CG, Piotrowska Z, Huynh TG, Zhao L, Fulton L, Schultz KR, Howe E, Farago AF, Sullivan RJ, Stone JR, Digumarthy S, Moran T, Hata AN, Yagi Y, Yeap BY, Engelman JA, MinoKenudson M (2016) EGFR mutations and ALK rearrangements are associated with low response rates to PD-1 pathway blockade in non-small cell lung cancer: a retrospective analysis. Clin Cancer Res 22(18): 4585-4593.

Garbe C, Peris K, Hauschild A, Saiag P, Middleton M, Bastholt L, Grob J-J, Malvehy J, Newton-Bishop J, Stratigos AJ, Pehamberger H, Eggermont AM (2016) Diagnosis and treatment of melanoma. European consensusbased interdisciplinary guideline - Update 2016. Eur J Cancer 63: 201-217.

Garon EB, Rizvi NA, Hui R, Leighl N, Balmanoukian AS, Eder JP, Patnaik A, Aggarwal C, Gubens M, Horn L, Carcereny E, Ahn M-J, Felip E, Lee J-S, Hellmann MD, Hamid O, Goldman JW, Soria J-C, Dolled-Filhart M,
Rutledge RZ, Zhang J, Lunceford JK, Rangwala R, Lubiniecki GM, Roach C, Emancipator K, Gandhi L (2015) Pembrolizumab for the treatment of non-small-cell lung cancer. $N$ Engl J Med 372(21): 2018-2028.

Gebhardt C, Sevko A, Jiang H, Lichtenberger R, Reith M, Tarnanidis K, Holland-Letz T, Umansky L, Beckhove P, Sucker A, Schadendorf D, Utikal J, Umansky V (2015) Myeloid cells and related chronic inflammatory factors as novel predictive markers in melanoma treatment with Ipilimumab. Clin Cancer Res 21(24): 5453-5459.

Gnjatic S, Bronte V, Brunet LR, Butler MO, Disis ML, Galon J, Hakansson LG, Hanks BA, Karanikas V, Khleif SN, Kirkwood JM, Miller LD, Schendel DJ, Tanneau I, Wigginton JM, Butterfield LH (2017) Identifying baseline immune-related biomarkers to predict clinical outcome of immunotherapy. J Immunother Cancer 5(1): 44.

Hellmann MD, Creelan BC, Woo K, Sima CS, Iams WT, Antonia SJ, Horn L, Brahmer JR, Gettinger S, Harbison C, Rizvi N (2014) 1229pdsmoking history and response to Nivolumab in patients with advanced NSCLCS. Ann Oncol 25(suppl 4; iv429): iv426-iv470.

Henze J, Maintz D, Persigehl T (2016) RECIST 1.1, irRECIST 1.1, and mRECIST: how to do. Curr Radiol Rep 4(9): 48.

Horvat TZ, Adel NG, Dang TO, Momtaz P, Postow MA, Callahan MK, Carvajal RD, Dickson MA, D’Angelo SP, Woo KM, Panageas KS, Wolchok JD, Chapman PB (2015) Immune-related adverse events, need for systemic immunosuppression, and effects on survival and time to treatment failure in patients with melanoma treated with Ipilimumab at Memorial Sloan Kettering Cancer Center. J Clin Oncol 33(28): 3193-3198.

Hua C, Boussemart L, Mateus C, Routier E, Boutros C, Cazenave H, Viollet R, Thomas M, Roy S, Benannoune N, Tomasic G, Soria JC, Champiat S, Texier M, Lanoy E, Robert C (2016) Association of Vitiligo with tumor response in patients with metastatic melanoma treated with Pembrolizumab. JAMA Dermatol 152(1): 45-51.

Johnson DB, Sullivan RJ, Menzies AM (2017) Immune checkpoint inhibitors in challenging populations. Cancer 123(11): 1904-1911.

Kelderman S, Heemskerk B, van Tinteren H, van den Brom RRH, Hospers GAP, van den Eertwegh AJM, Kapiteijn EW, de Groot JWB, Soetekouw P, Jansen RL, Fiets E, Furness AJS, Renn A, Krzystanek M, Szallasi Z, Lorigan $\mathrm{P}$, Gore ME, Schumacher TNM, Haanen JBAG, Larkin JMG, Blank CU (2014) Lactate dehydrogenase as a selection criterion for ipilimumab treatment in metastatic melanoma. Cancer Immunol Immunother 63(5): 449-458.

Khoja L, Atenafu EG, Templeton A, Qye Y, Chappell MA, Saibil S, Hogg D, Butler MO, Joshua AM (2016) The full blood count as a biomarker of outcome and toxicity in ipilimumab-treated cutaneous metastatic melanoma. Cancer Med 5(10): 2792-2799.

Ku GY, Yuan J, Page DB, Schroeder SEA, Panageas KS, Carvajal RD, Chapman PB, Schwartz GK, Allison JP, Wolchok JD (2010) Singleinstitution experience with ipilimumab in advanced melanoma patients in the compassionate use setting. Cancer 116(7): 1767-1775.

Maio M, Grob J-J, Aamdal S, Bondarenko I, Robert C, Thomas L, Garbe C, Chiarion-Sileni V, Testori A, Chen T-T (2015) Five-year survival rates for treatment-naive patients with advanced melanoma who received ipilimumab plus dacarbazine in a phase III trial. J Clin Oncol 33(10): 1191-1196.

Manson G, Norwood J, Marabelle A, Kohrt H, Houot R (2016) Biomarkers associated with checkpoint inhibitors. Ann Oncol 27(7): 1199-1206.

Martens A, Wistuba-Hamprecht K, Foppen MG, Yuan J, Postow MA, Wong P, Romano E, Khammari A, Dreno B, Capone M, Ascierto PA, Di Giacomo AM, Maio M, Schilling B, Sucker A, Schadendorf D, Hassel JC, Eigentler TK, Martus P, Wolchok JD, Blank C, Pawelec G, Garbe C, Weide B (2016a) Baseline peripheral blood biomarkers associated with clinical outcome of advanced melanoma patients treated with Ipilimumab. Clin Cancer Res 22(12): 2908-2918.

Martens A, Wistuba-Hamprecht K, Yuan J, Postow MA, Wong P, Capone M, Madonna G, Khammari A, Schilling B, Sucker A, Schadendorf D, Martus P, Dreno B, Ascierto PA, Wolchok JD, Pawelec G, Garbe C, Weide B (2016b) Increases in absolute lymphocytes and circulating $\mathrm{CD} 4+$ and CD8 + T cells are associated with positive clinical outcome of melanoma patients treated with ipilimumab. Clin Cancer Res 22(19): $4848-4858$.

Meng X, Huang Z, Teng F, Xing L, Yu J (2015) Predictive biomarkers in PD-1/ PD-L1 checkpoint blockade immunotherapy. Cancer Treat Rev 41(10): 868-876. 
Motzer RJ, Escudier B, McDermott DF, George S, Hammers HJ, Srinivas S, Tykodi SS, Sosman JA, Procopio G, Plimack ER, Castellano D, Choueiri TK, Gurney H, Donskov F, Bono P, Wagstaff J, Gauler TC, Ueda T, Tomita Y, Schutz FA, Kollmannsberger C, Larkin J, Ravaud A, Simon JS, Xu L-A, Waxman IM, Sharma P (2015) Nivolumab versus Everolimus in advanced renal-cell carcinoma. $N$ Engl J Med 373(19): 1803-1813.

Nakamura Y, Kitano S, Takahashi A, Tsutsumida A, Namikawa K, Tanese K, Abe T, Funakoshi T, Yamamoto N, Amagai M, Yamazaki N (2016) Nivolumab for advanced melanoma: pretreatment prognostic factors and early outcome markers during therapy. Oncotarget 7(47): 77404-77415.

Nishijima TF, Muss HB, Shachar SS, Moschos SJ (2016) Comparison of efficacy of immune checkpoint inhibitors (ICIs) between younger and older patients: a systematic review and meta-analysis. Cancer Treat Rev 45: 30-37.

Oh DY, Cham J, Zhang L, Fong G, Kwek SS, Klinger M, Faham M, Fong L (2017) Immune toxicities elicted by CTLA-4 blockade in cancer patients are associated with early diversification of the T-cell repertoire. Cancer Res 77(6): 1322-1330.

Pardoll DM (2012) The blockade of immune checkpoints in cancer immunotherapy. Nat Rev Cancer 12(4): 252-264.

Postow MA, Chesney J, Pavlick AC, Robert C, Grossmann K, McDermott D, Linette GP, Meyer N, Giguere JK, Agarwala SS, Shaheen M, Ernstoff MS, Minor D, Salama AK, Taylor M, Ott PA, Rollin LM, Horak C, Gagnier P, Wolchok JD, Hodi FS (2015) Nivolumab and Ipilimumab versus Ipilimumab in untreated melanoma. N Engl J Med 372(21): 2006-2017.

Powles T, Jin C, Zheng Y, Baverel P, Narwal R, Mukhopadhyay P, Jin X, Dennis PA, Gupta AK, Ben Y, Ho TW, Roskos L (2017) Tumor shrinkage and increased overall survival are associated with improved albumin, neutrophil lymphocyte ratio (NLR) and decreased durvalumab clearance in NSCLC and UC patients receiving durvalumab. J Clin Oncol 35(15_suppl): 3035.

Remon J, Chaput N, Planchard D (2016) Predictive biomarkers for programmed death-1/programmed death ligand immune checkpoint inhibitors in nonsmall cell lung cancer. Curr Opin Oncol 28(2): 122-129.

Ribas A, Puzanov I, Dummer R, Schadendorf D, Hamid O, Robert C, Hodi FS, Schachter J, Pavlick AC, Lewis KD, Cranmer LD, Blank CU, O'Day SJ, Ascierto PA, Salama AKS, Margolin KA, Loquai C, Eigentler TK, Gangadhar TC, Carlino MS, Agarwala SS, Moschos SJ, Sosman JA, Goldinger SM, Shapira-Frommer R, Gonzalez R, Kirkwood JM, Wolchok JD, Eggermont A, Li XN, Zhou W, Zernhelt AM, Lis J, Ebbinghaus S, Kang SP, Daud A (2015) Pembrolizumab versus investigator-choice chemotherapy for ipilimumab-refractory melanoma (KEYNOTE-002): a randomised, controlled, phase 2 trial. Lancet Oncol 16(8): 908-918.

Rittmeyer A, Barlesi F, Waterkamp D, Park K, Ciardiello F, von Pawel J, Gadgeel SM, Hida T, Kowalski DM, Dols MC, Cortinovis DL, Leach J, Polikoff J, Barrios C, Kabbinavar F, Frontera OA, De Marinis F, Turna H, Lee J-S, Ballinger M, Kowanetz M, He P, Chen DS, Sandler A, Gandara DR (2016) Atezolizumab versus docetaxel in patients with previously treated non-small-cell lung cancer (OAK): a phase 3, open-label, multicentre randomised controlled trial. Lancet 389(10066): 255-265.

Robert C, Long GV, Brady B, Dutriaux C, Maio M, Mortier L, Hassel JC, Rutkowski P, McNeil C, Kalinka-Warzocha E, Savage KJ, Hernberg MM, Lebbé C, Charles J, Mihalcioiu C, Chiarion-Sileni V, Mauch C, Cognetti F, Arance A, Schmidt H, Schadendorf D, Gogas H, Lundgren-Eriksson L, Horak C, Sharkey B, Waxman IM, Atkinson V, Ascierto PA (2015) Nivolumab in previously untreated melanoma without BRAF mutation. $N$ Engl J Med 372(4): 320-330.

Robert C, Schachter J, Long GV, Arance A, Grob JJ, Mortier L, Daud A, Carlino MS, McNeil C, Lotem M, Larkin J, Lorigan P, Neyns B, Blank CU, Hamid O, Mateus C, Shapira-Frommer R, Kosh M, Zhou H, Ibrahim N, Ebbinghaus S, Ribas A (2015) Pembrolizumab versus Ipilimumab in advanced melanoma. N Engl J Med 372(26): 2521-2532.

Rosenberg JE, Hoffman-Censits J, Powles T, van der Heijden MS, Balar AV, Necchi A, Dawson N, O’Donnell PH, Balmanoukian A, Loriot Y, Srinivas S, Retz MM, Grivas P, Joseph RW, Galsky MD, Fleming MT, Petrylak DP, Perez-Gracia JL, Burris HA, Castellano D, Canil C, Bellmunt J, Bajorin D, Nickles D, Bourgon R, Frampton GM, Cui N, Mariathasan S, Abidoye O, Fine GD, Dreicer R (2016) Atezolizumab in patients with locally advanced and metastatic urothelial carcinoma who have progressed following treatment with platinum-based chemotherapy: a single-arm, multicentre, phase 2 trial. Lancet 387(10031): 1909-1920.
Schindler K, Harmankaya K, Kuk D, Mangana J, Michielin O, Hoeller C, Dummer R, Pehamberger H, Wolchok JD, Postow MA (2014) Correlation of absolute and relative eosinophil counts with immune-related adverse events in melanoma patients treated with ipilimumab; ASCO Annual Meeting Proceedings. J Clin Oncol 32, (15_suppl; abstr 9096).

Seetharamu N, Budman DR, Sullivan KM (2016) Immune checkpoint inhibitors in lung cancer: past, present and future. Future Oncol 12(9): 1151-1163.

Seliger B (2016) Molecular mechanisms of HLA class I-mediated immune evasion of human tumors and their role in resistance to immunotherapies. HLA 88(5): 213-220.

Sharma P, Retz M, Siefker-Radtke A, Baron A, Necchi A, Bedke J, Plimack ER, Vaena D, Grimm M-O, Bracarda S, Arranz JÁ, Pal S, Ohyama C, Saci A, Qu X, Lambert A, Krishnan S, Azrilevich A, Galsky MD (2017) Nivolumab in metastatic urothelial carcinoma after platinum therapy (CheckMate 275): a multicentre, single-arm, phase 2 trial. Lancet Oncol 18(3): 312-322.

Simeone E, Gentilcore G, Giannarelli D, Grimaldi AM, Caracò C, Curvietto M, Esposito A, Paone M, Palla M, Cavalcanti E, Sandomenico F, Petrillo A, Botti G, Fulciniti F, Palmieri G, Queirolo P, Marchetti P, Ferraresi V, Rinaldi G, Pistillo MP, Ciliberto G, Mozzillo N, Ascierto PA (2014) Immunological and biological changes during ipilimumab treatment and their potential correlation with clinical response and survival in patients with advanced melanoma. Cancer Immunol Immunother 63(7): 675-683.

Sorich MJ, Rowland A, Kichenadasse G, Woodman RJ, Mangoni AA (2016) Risk factors of proteinuria in renal cell carcinoma patients treated with VEGF inhibitors: a secondary analysis of pooled clinical trial data. $\mathrm{Br} \mathrm{J}$ Cancer 114(12): 1313-1317.

Tarhini AA, Zahoor H, Lin Y, Malhotra U, Sander C, Butterfield LH, Kirkwood JM (2015) Baseline circulating IL-17 predicts toxicity while TGF- $\beta 1$ and IL-10 are prognostic of relapse in ipilimumab neoadjuvant therapy of melanoma. J Immunother Cancer 3(1): 39.

Teulings HE, Limpens J, Jansen SN, Zwinderman AH, Reitsma JB, Spuls PI, Luiten RM (2015) Vitiligo-like depigmentation in patients with stage IIIIV melanoma receiving immunotherapy and its association with survival: a systematic review and meta-analysis. J Clin Oncol 33(7): 773-781.

Topalian SL, Taube JM, Anders RA, Pardoll DM (2016) Mechanism-driven biomarkers to guide immune checkpoint blockade in cancer therapy. Nat Rev Cancer 16(5): 275-287.

Valpione S, Martinoli C, Fava P, Mocellin S, Campana LG, Quaglino P, Ferrucci PF, Pigozzo J, Astrua C, Testori A, Chiarion-Sileni V (2015) Personalised medicine: development and external validation of a prognostic model for metastatic melanoma patients treated with ipilimumab. Eur J Cancer 51(14): 2086-2094.

Wargo JA, Gopalakrishnan V, Spencer C, Karpinets T, Reuben A, Andrews MC, Tetzlaff MT, Lazar A, Hwu P, Hwu W-J, Glitza IC, Tawbi HA-H, Patel SP, Lee JE, Davies MA, Gershenwald JE, Futreal A, Sharma P, Allison JP, Jenq RR (2017) Association of the diversity and composition of the gut microbiome with responses and survival (PFS) in metastatic melanoma (MM) patients (pts) on anti-PD-1 therapy. J Clin Oncol 35(15_suppl): 3008.

Weber JS, D'Angelo SP, Minor D, Hodi FS, Gutzmer R, Neyns B, Hoeller C, Khushalani NI, Miller Jr WH, Lao CD, Linette GP, Thomas L, Lorigan P, Grossmann KF, Hassel JC, Maio M, Sznol M, Ascierto PA, Mohr P, Chmielowski B, Bryce A, Svane IM, Grob J-J, Krackhardt AM, Horak C, Lambert A, Yang AS, Larkin J (2015) Nivolumab versus chemotherapy in patients with advanced melanoma who progressed after anti-CTLA-4 treatment (CheckMate 037): a randomised, controlled, open-label, phase 3 trial. Lancet Oncol 16(4): 375-384.

Weber JS, Hodi FS, Wolchok JD, Topalian SL, Schadendorf D, Larkin J, Sznol M, Long GV, Li H, Waxman IM, Jiang J, Robert C (2017) Safety profile of Nivolumab monotherapy: a pooled analysis of patients with advanced melanoma. J Clin Oncol 7: 785-792.

Weide B, Martens A, Hassel JC, Berking C, Postow MA, Bisschop K, Simeone E, Mangana J, Schilling B, Di Giacomo A-M, Brenner N, Kähler KC, Heinzerling L, Gutzmer R, Bender A, Gebhardt C, Romano E, Meier F, Martus P, Maio M, Blank CU, Schadendorf D, Dummer R, Ascierto PA, Hospers GA, Garbe C, Wolchok JD (2016) Baseline biomarkers for outcome of melanoma patients treated with pembrolizumab. Clin Cancer Res 22(22): 5487-5496.

Wolchok JD, Kluger H, Callahan MK, Postow MA, Rizvi NA, Lesokhin AM, Segal NH, Ariyan CE, Gordon R-A, Reed K, Burke MM, Caldwell A, Kronenberg SA, Agunwamba BU, Zhang X, Lowy I, Inzunza HD, Feely W, 
Horak CE, Hong Q, Korman AJ, Wigginton JM, Gupta A, Sznol M (2013) Nivolumab plus Ipilimumab in advanced melanoma. N Engl J Med 369(2): 122-133.

Zaragoza J, Caille A, Beneton N, Bens G, Christiann F, Maillard H, Machet L (2016) High neutrophil to lymphocyte ratio measured before starting ipilimumab treatment is associated with reduced overall survival in patients with melanoma. Br J Dermatol 174(1): 146-151. (c) (i) This work is licensed under the Creative Commons Attribution 4.0 International License. To view a copy of this license, visit http://creativecommons.org/licenses/by/4.0/

(C) The Author(s) named above 2017 